\title{
Nutritional innovations on amino acids supplementation in Nile tilapia diets
}

\author{
Wilson Massamitu Furuya ${ }^{1}$, Valéria Rossetto Barriviera Furuya ${ }^{2}$
}

\author{
${ }^{1}$ Departamento de Zootecnia - Universidade Estadual de Maringá, Brazil. \\ 2 Departamento de Zootecnia - Universidade Estadual de Ponta Grossa, Paraná, Brazil.
}

\begin{abstract}
The optimal dietary supply of amino acids to tilapia has been studied for many years. Nevertheless, a general agreement on the amino acid requirement for tilapias has not been established. In order to optimize efficiency and reduce surplus nitrogen, values of digestibility of each amino acid of feed must be considered. Due to variations in the amino acid requirement due to new tilapia strains introduction, continuous research on amino acid requirements is necessary to elaborate economical and environmental sustainability diets, also improving fish growth, efficiency and fillet yield. The concept of ideal protein in tilapia diets was introduced more than ten years ago, and new researches have shown the importance of protein and amino acids on fish performance and health, when tilapias are submitted to constant challenging from internal and external factors.
\end{abstract}

Key Words: amino acids, digestibility, fish, ideal protein, meat quality, performance

\section{Inovações sobre o uso de aminoácidos industriais em dietas para a tilápia-do-nilo}

RESUMO - O suprimento adequado de aminoácidos dietéticos para tilápias tem sido estudado por muitos anos. No entanto, ainda não foi estabelecida uma concordância geral sobre a exigência de aminoácidos para tilápias. A fim de otimizar a eficiência e reduzir o excesso de nitrogênio, as dietas devem ser elaboradas considerando-se os valores de digestibilidade de cada aminoácido dos alimentos. Devido às variações nas exigências de aminoácidos pela introdução novas linhagens de tilápias, a investigação contínua sobre exigências de aminoácidos é necessária para a elaboração de dietas ambiental e economicamente sustentáveis que melhorem também o crescimento dos peixes, a eficiência alimentar e o rendimento de filé. O conceito de proteína ideal em dietas de tilápias foi introduzido há mais de dez anos, e novas pesquisas têm mostrado a importância da proteína e aminoácidos no desempenho e na saúde dos peixes submetidos a desafios frente a fatores internos e externos.

Palavras-chave: aminoácidos, desempenho, digestibilidade, proteína ideal, peixes, qualidade da carne

\section{Introduction}

Aquaculture feeds are among the most expensive animal feed on the market due to the use of high levels of expensive ingredients and processing used. As global fish farming continues to increase, the need for balanced and cost-effective protein sources is important.

In order to improve cost-effectiveness of feeds, fish meal has been replaced by more economical protein source, as soybean meal, meat and bone meal, blood meal, feather meal and poultry viscera meal, where the need for more attention to the quantitative and qualitative amino values of fish diets is necessary.

Because of the complex interactions between endogenous and environmental factors, related to the great diversity of fish species and ingredients studied, and methodological approach used, understanding of "stateof-the-art" of fish nutrition in aquaculture nutrition is often difficult (Hua \& Bureau, 2009). However, a lot of progress has been achieved on the role of amino acids in tilapia nutrition to better meet current challenges in intensive tilapia production in Brazilian conditions.

In Brazil, in recent years many researchers have been carried out to determine the nutritional requirements of amino acids, mineral, vitamins for Nile tilapia (Oreochromis niloticus), and its effects on fish growth and health has been critically analyzed, especially in commercial conditions, where fish are submitted to constant challenging from internal and external factors (Barros et al., 2009). The physiological state of the fish also keeps nutrient requirements in constant flux, as requirements may change with environmental conditions, perturbations to the health status, and the size or age of the fish (Wilson, 2002).

The Nile tilapia is one of the most important cultured fish species in Brazil, where tilapia production has been changed from traditional culture in earth ponds to more intensive culture in cages. Tilapia culture has been playing an increasing important role in the economy of many 
Brazilian regions over the past two decades. The study of tilapia nutrition and feeding as cultured fish species is, year after year, the focus of many research groups, and the importance of amino acids on fish nutrition and feeding is rapidly expanding.

This paper is a review of recent researches carried out at Brazilian conditions on the use of dietary industrial amino acids in commercial and experimental diets, designed in practical and laboratorial conditions to develop information's to be used as tools to address challenges in tilapia production.

\section{Amino acid source and digestibility}

Fish meal has been used as reference protein source in tilapia diets, showing high content of protein with well balanced amino acids, high palatability and good source of energy, essential fatty acids, minerals and vitamins. However, fish meal production has remained stable and soybean meal has been considered the most promising vegetal protein source to substitute fish meal, mainly in non carnivorous fish diets (Pezzato et al., 2009).

The use of plant ingredients such as soy protein derivatives has received increasing attention as potential substitutes for fish proteins. However, plant proteins often show deficiencies in some essential amino acids and several antinutritional factors. When compared to fish meal, soybean meal has low levels of digestible energy, available phosphorus and digestible methionine (Furuya et al., 2001), and higher contents of fiber (Pezzato et al., 2002).

Recently, feather meal, blood meal, meat and bone meal have been used to substitute fish meal in commercial diets for Nile tilapia in Brazil. The apparent digestibility coefficients of protein and amino acids of these ingredients are lower when compared to soybean meal (Furuya et al., 2001; Pezzato et al., 2002; Guimarães et al., 2008a,b) and digestibility coefficient of individual amino acid is necessary to be considered to elaborate well balanced amino acids diets to sustain tilapia performance.

In practical condition, elaborating commercial diets is not so easy, as amino acid composition of ingredients depends on many factors. In terms of protein level and digestibility, soybean meal is one of the most homogeneous ingredient used to elaborate practical diets. However, a great variation of amino acids contents can be observed when individual amino acids value is considered (Figure 1).

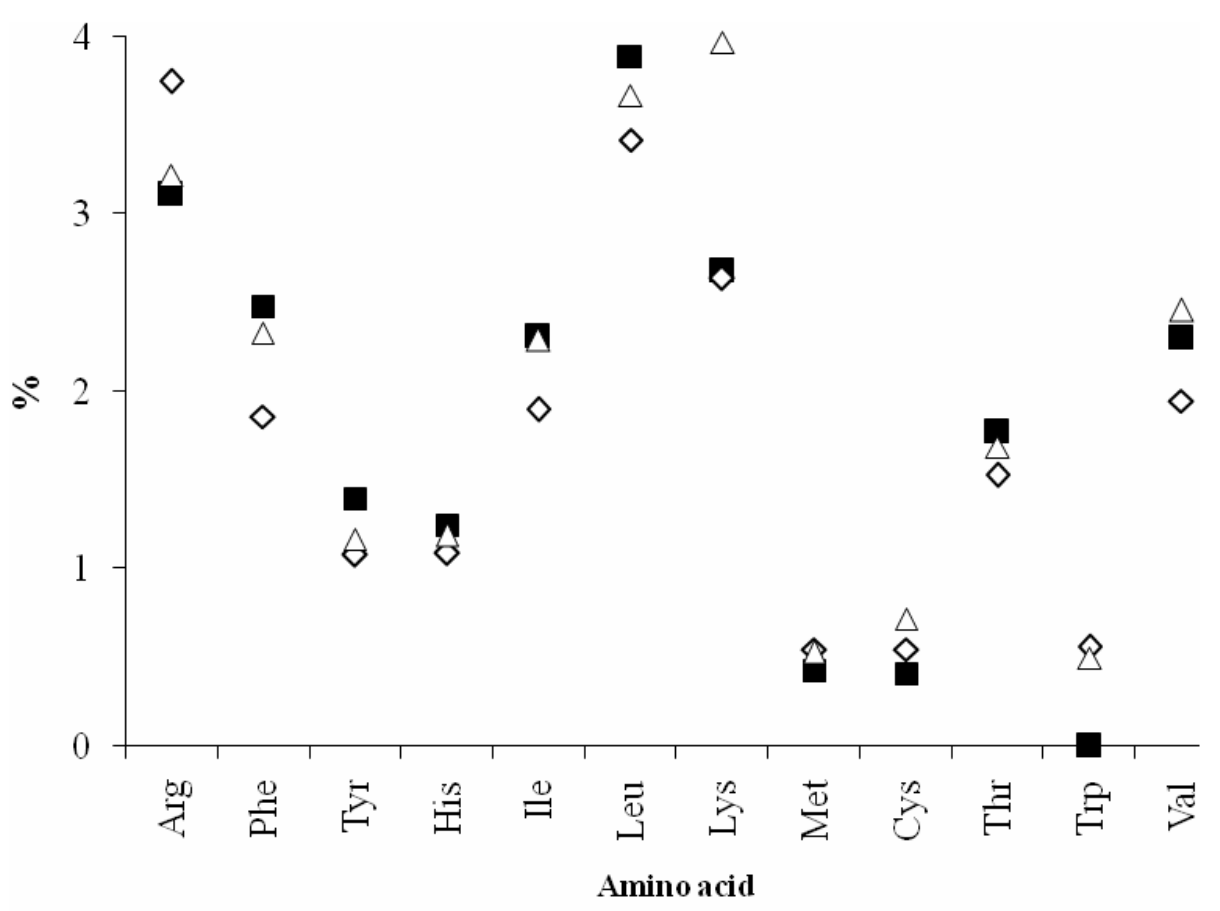

Gonçalves (2007) $\diamond$ Furuya et al. (2001) $\Delta$ Guimarães et al. (2008a)

Figure 1 - Essential amino acids contents (including cystine and tyrosine) of soybean meal, measured by different authors (as-fed basis). 
Poultry viscera meal has been shown to be a good alternative for fish meal in digestibility studies using Nile tilapia (Guimarães et al., 2008a). Digestibility of meat and bone meal may vary significantly and the freshness of the raw material and processing conditions used may seriously affect the protein digestibility when used as feed ingredient for fish diets. Protein level is shown to be a good indicator for differences in protein digestibility due to processing conditions and/or the raw material used.

Recently, Vidal (2010) elaborated an equation to estimate digestible protein values of meat and bone meal according to the chemical composition (Figure 2).

However, more studies are necessary to support high tilapia production in Brazilian conditions in earth ponds and cages, where protein and amino acids are necessary to be considered not only because of fish growth and feed conversion ratio, but fillet yield and meat quality must be considered.

Blood meal is a common animal protein source used in fish diet in Brazil. However, digestibility of blood meal may vary according to the processing conditions (i.e. temperature) used as feed ingredient for fish.

\section{Amino acids requirements of tilapias}

Amino acids requirement for tilapias are published by the NRC (1993). However, the experiments upon which these requirements are based are dated and do not account for the genetic progress, diet processing technology and feed management occurred.

Because multiple factors affect amino acids requirements, estimations of amino acids requirements of fish should be based on the ideal amino acid profile (Wilson \& Poe 1991; Furuya et al., 2004b). In Brazil, many experiments have been still performed under different experimental conditions with different basal diets, ages, and genetic

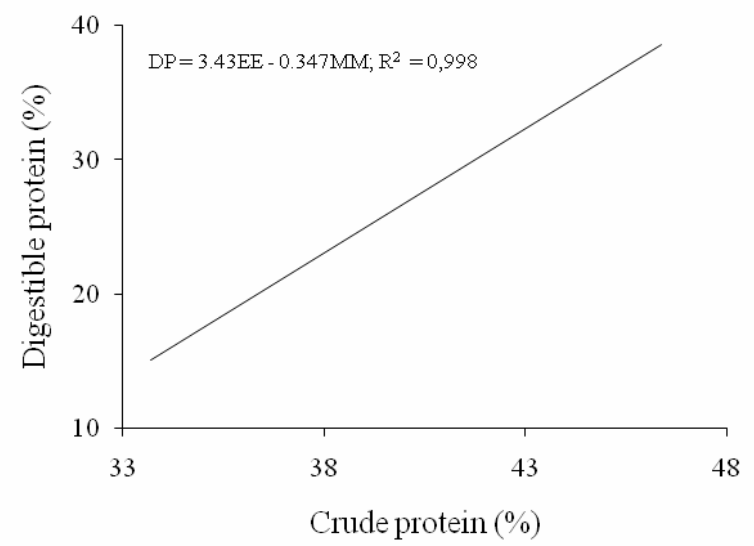

Figure 2 - Estimated digestible protein values of meat and bone meal using mathematical modeling (Vidal, 2010). lines, using digestible values of amino acids from ingredients and considering a valid measurement of the ideal amino acids profile.

The NRC (1993) reported determined essential amino acids requirements for Nile tilapia; however, these profile was estimated from only one experiment using small fish and purified diet. Dietary quantitative amino acids are known to be reduced according to fish age or weigh, and using same quantitative amino acids for 10 to $800 \mathrm{~g}$ fish is not recommended as "nutritional point of view” to elaborate balanced diets.

In practical diets, methionine to cystine ratio is different from purified protein sources, especially, albumin, casein and gelatin, and methionine requirement of $0.75 \%$ is considered high to be supplemented in practical diets. Based on some information's from researches realized in Brazil, methionine is necessary as approximately 55\% of total sulfured amino acids.

Lysine is one of the most limiting amino acids in fish nutrition, not only related to fish growth, but to increases fillet yield (Furuya et al., 2006). In practical conditions, it is possible that two fish have the same weight, but produce different values of fillet yield. Quantitative dietary lysine is showed as 5.5 to $6 \%$ of the dietary protein (Furuya et al., 2001, 2004a, 2009; Takishita et al., 2009; Bomfim et al., 2010), higher than the value recommended by NRC (1993) for tilapias (5.1\% of protein).

Threonine supplementation is associated to tilapia growth (Bomfim et al., 2008a) and fillet yield improving (Silva et al., 2006), specially in diets formulated based on soybean protein (amino acids), indicating that threonine is a limiting amino acid in soybean meal when meat production is considered.

A few information's are available for arginine, tryptophan and others essential amino acids requirements of tilapias cultured in Brazil. To elaborate low protein diets, is expected that many others essential and non-essential amino acids requirements will be determined to avoid amino acids deficiencies in fish diets.

As amino acids composition from whole body fish can be used to estimate amino acid requirement of fish, an estimated values of essential amino acid requirements are showed in Table 1.

The relationship between whole body amino acid patterns and amino acid requirement determined using dose-response experiments was observed by Wilson \& Poe (1981) in the study conducted to evaluate the relationship of whole body and egg essential amino acid patterns to amino acid requirement patterns in channel catfish (Ictalurus puncatus). 
Table 1 - Essential amino acid (EEA) including cystine and tyrosine to lysine $(\mathrm{L})$ ratios in whole body composition of Nile tilapia

\begin{tabular}{lc}
\hline Amino acid & EAA/L ratio (\%) \\
\hline Lysine & 100.00 \\
Arginine & 89.67 \\
Histidine & 35.69 \\
Isoleucine & 62.24 \\
Leucine & 66.67 \\
Methionine + cystine & 52.51 \\
Phenilalanine + tyrosine & 115.04 \\
Threonine & 69.03 \\
Tryptopan & 11.44 \\
Valine & 67.55 \\
\hline
\end{tabular}

$\mathrm{EAA} / \mathrm{L}=$ essential amino acid (including cystine and tyrosine) to lysine ratio (Teixeira et al., 2008).

\section{Ideal amino acid patterns}

The ideal amino acids profile = ideal protein concept, employs the concept that, whereas absolute amino acids requirements change due to genetic or environmental factors, but the ratios among them are only slightly affected. Once the ideal amino acid profile has been determined, the requirement for a single amino acids can be determined experimentally for a given field situation and the requirements for all other amino acids are calculated from the ideal ratios. This concept has been adopted by the swine industry, as well the broiler industry, and initially applied in fish diets in Brazil by Furuya et al. (2004b), using DL-methionine, L-lysine as supplemented amino acids.

In Brazil, many experiments were realized to investigate responses of fish fed to graded dietary inclusions of the essential amino acids lysine, methionine and threonine, to determine the ideal amino acids ratios of the assayed amino acids relative to Lysine. Methionine + cystine requirement based on ideal protein concept is approximately $60 \%$ of lysine, regardless of fish age or weight (Figure 3).

Arai (1981) used essential amino acid content/total amino acid content (including cystine and tyrosine) x 1000 (A/E) of whole body coho salmon (Oncorhynchus kisutch) fry to formulate test diet for this. The author found that fish fed casein diets supplemented with amino acids to simulate A/E ratios of fish body tissue showed much improved growth and feed efficiency. Ogata et al. (1983) used this technique to estimate the amino acid requirements of salmon (Oncorhynchus masou), and Forster \& Ogata et al. (1998) used this method to estimate amino acid requirements of Japanese flounder (Paralichthys olivaceus) and red sea bream (Pagrus major). This method has been used in silver perch (Ngamsnae et al., 1999) and jundiá (Rhamdia quelen).

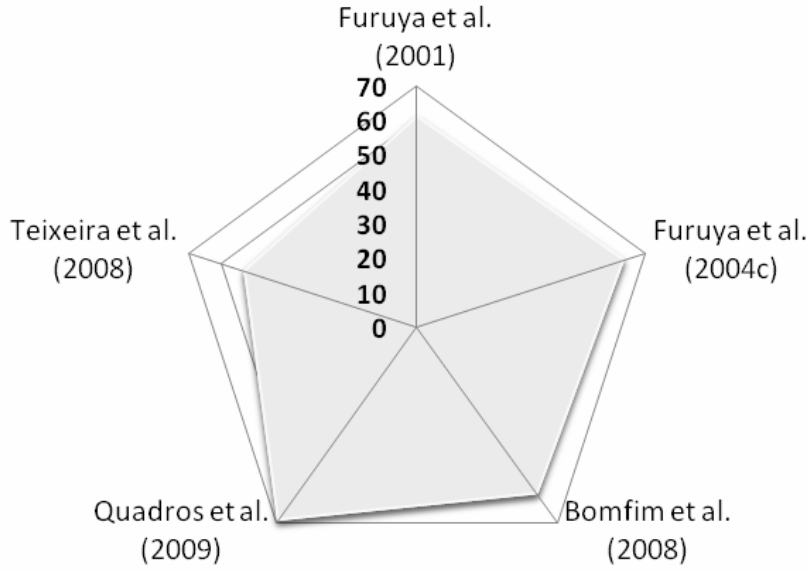

Figure 3 - Methionine + cystine requirement of Nile tilapia based on ideal protein concept.

Furuya et al. (2001, 2004c), Bomfim et al. (2008) and Quadros et al. (2009), values determined using dose-response researches.

Teixeira et al. (2008), based on amino acids composition of tilapia whole body.

Reducing dietary protein by amino acids supplementation

Reducing dietary protein content is important to formulate cost effective and low pollution diets, especially when fish are cultured in intensive system, where fish requirement are supplied by nutrients provided by food. Nitrogen is one of the most pollution nutrients in fish diets and high protein digestibility diets are required to reduce environmental pollution without negative effects on fish performance.

Fish growth is determined by the first limiting amino acid and reducing the protein content of fish feeds is one strategy to increase the sustainability of tilapia production via reducing feed costs as well as reducing the environmental impact if economical growth can be maintained with less nitrogen input.

The possibility of reducing the dietary protein was demonstrated in diets for carp (Viola \& Lahav, 1991), Nile tilapia (Furuya et al., 2005; Botaro et al., 2007), rainbow trout (Cheng et al., 2003, Gaylord \& Barrows, 2009). The ideal protein concept should be used to balance amino acids of fish diets (Wilson \& Poe, 1991; Furuya et al., 2004b).

Amino acids and fish health

The gradual development of antibiotic resistance in farm animals has pressured nutritionists to find alternative ways of achieving high production and healthy animals. Nutritional supplements are being considered as a means to bolster the immune system, and improve gastrointestinal defense mechanisms against invasive bacteria. Glutamine, arginine and threonine are involved in many maintenance 
functions, in particular of the immune system and in gut mucosal repair processes (Bequette, 2003).

The intestine represents the first barrier to food-borne antigens and bacteria. The high rate of protein turnover in the gut ensures that damaged tissues are rapidly shed and large amounts of mucins are secreted to create a barrier to bacterial translocation. Mucosal cells and intraepithelial lymphocytes have and obligate requirement for glutamine as energy source, and for the synthesis of other nonessential amino acids and nucleotide bases (Wu et al., 1996). The nutritional supply of glutamine may become limited during intestine stress, and glutamine supplementation reduces intestine villi atrophy and improves weight gain (Silva, 2008). The effectiveness of glutamine may depend on whether the digestive insult challenges (Bequette, 2003).

Mucins act as a barrier to infection and antigen materials presented to the gut. In fish, mucins are secreted by the skin for external protection, and are rich in threonine, proline, serine and cysteine and dietary tannins, indigestible fibers, intestinal diseases induce gut atrophy and increase mucin secretion (Bequete, 2003).

Ecnonomical responses of market size Nile tilapia to amino acids

The mains objective of modern fish production in defined by return on capital employed and feed cost per kg live weigh gain, uniformity, weigh gain, carcass yield and fillet yield are used as performance indicators. More recently, feed cost per kg of gain and feed cost per kg fillet meat produced were introduced by Silva et al. (2006) and Botaro et al. (2007) as variable to choose the best level of threonine and protein in Nile tilapia diets, respectively.

In requirements studies, fitting response curves to the experimental data has been suggested as the preferred way of evaluation, and non-linear models, linear Broken Line dose response have been suggested. However, in practical situation, in addition to weight gain and feed conversion ratio, "feed cost per kg live weight" and "feed cost per kg fillet meat" are necessary to be calculated as economical variables, since the cost of feeding is high in intensive fish production.

As determined by Botaro et al. (2007), the response in feed cost per kg fillet meat to increasing amino acid levels is not only affected by the feed to gain ratio, but by the increasing yield of fillet meat as percentage of live weight. Evaluating graded levels of dietary threonine in Nile tilapia diets, Silva et al. (2006) observed that the economic optima as feed cost per kg live weight occurred at $0.92 \%$ of threonine (Table 2).
Table 2 - Diet cost, cost per kg of live weight gain and cost per $\mathrm{kg}$ of fillet meat gain of Nile tilapia fed diets with increasing threonine levels

\begin{tabular}{|c|c|c|c|c|c|}
\hline \multirow[t]{2}{*}{ Cost } & \multicolumn{4}{|c|}{ Threonine level (\%) } & \multirow[t]{2}{*}{$\mathrm{CV}^{*}$} \\
\hline & 0.92 & 1.06 & 1.21 & 1.35 & \\
\hline Diet cost (R\$/kg) & 0.60 & 0.62 & 0.64 & 0.67 & 0.73 \\
\hline $\begin{array}{l}\text { Cost per kg of live } \\
\text { weight gain }(\$)\end{array}$ & 1.00 & 1.07 & 1.02 & 1.01 & 6.22 \\
\hline $\begin{array}{l}\text { Cost per kg of fillet } \\
\text { meat gain }(\mathrm{R} \$)\end{array}$ & 2.67 & 2.86 & 2.65 & 2.68 & 8.81 \\
\hline
\end{tabular}

*Coefficient of variation.

Silva et al. (2006).

Moreover, the minimum cost per $\mathrm{kg}$ of fillet meat occurred at $1.21 \%$ of threonine, which is a difference of more than $30 \%$, substantial from an industrial point of view. But, the economic optimum levels can be altered by amino acid price changes.

Industrial amino acids and nitrogen emission and economic responses

The efficiency for protein synthesis is determined by the availability of the most limiting amino acid at the site of protein anabolism, and excess of amino acids is degraded and the surplus excreted nitrogen as ammonia depending on species. Animals retain protein in their body according to their potential growth and feed availability, age or body weight (Verstegen \& Jongbloed, 2003).

It is known that young fish deposit less energy and more protein than large fish. Furthemore, increased fat deposition and decreased rate of lean deposition occurs at an earlier growth stage, and dietary protein and amino acids levels can be precisely supplemented at each growth stage.

Aquaculture operations are confronted with the challenges of continuously improving their economical and environmental sustainability. Under precise feeding conditions, the quantity of nitrogen can be reduced by amino acids supplementation when dietary protein is reduced and/or dietary nitrogen is efficiently used by fish.

In Brazil, nutritionists have to focus on ways to avoid adding nitrogen to the environment. There are some ways to reduce nitrogen excretion by fish: reducing the amount of nitrogen consumed, by using highly digestible feedstuffs in diets and using amino acids supplementation is very effective in reducing nitrogen excretion, producing a high quality protein with superior amino acid balance to achieve an ideal protein basis to reduce excesses of unneeded amino acids, excreted as ammonia. 


\section{Final Considerations}

The profitability of fish production will partially hinge on the ability to formulate economically viable feeds that support efficient growth and healthy fish.

Determining the dietary amino acid requirement of tilapia will allow formulation of tilapia feeds with precision, because over formulation to meet limiting amino acid requirements will be reduced or eliminated. Balancing dietary amino acids in plant based feeds for tropical fish can reduce nitrogen losses from the fish and improve feed conversion ratios while maintaining rapid growth.

More researches are necessary to determine the dietary amino acid balance that maximize protein gain and amino acid retention, and address the economic value of alternative protein sources.

It is important to develop models to simulate and predict responses of amino acids supplementation on fish performance and cost production under variable conditions.

\section{References}

ARAI, S. A purified test diet for coho salmon, Oncorhynchus kisitch, fry. Bulletin of the Japanese Society of Scientif Fischeries, v.47, p.547-550, 1981.

BARROS, M.M.; RANZANI PAIVA, M.J.T.; PEZZATO, L.E. et al. Hematological response and growth performance of Nile Tilapia fed diets containing folic acid. Aquaculture Research, v.40, p.95-903, 2009.

BEQUETE, B.J. Amino acid metabolism in animals: an overview. In: D’MELLO, J.P.F. (Ed.) Amino acids in animal nutrition. Edinburgh: CABI, 2003. p.87-101.

BOMFIM, M.A.D.; LANNA, E.A.T.; DONZELE, J.L. et al. Exigência de treonina, com base no conceito de proteína ideal, de alevinos de tilápia-do-nilo. Revista Brasileira de Zootecnia, v.37, n.1, p.2077-2084, 2008a.

BOMFIM, M.A.D.; LANNA, E.A.T.; DONZELE, J.L. et al. Níveis de lisina, com base no conceito de proteína ideal, em rações para alevinos de tilápia-do-nilo. Revista Brasileira de Zootecnia, v.39, n,1, p.1-8, 2010.

BOTARO, D.; FURUYA, W.M.; SILVA, L.C.R. et al. Redução da proteína da dieta com base no conceito de proteína ideal para tilápias-do-nilo (Oreochromis niloticus) criadas em tanquesrede. Revista Brasileira de Zootecnia, v.36, n.3, p.517525, 2007.

CHENG, Z.J.; HARDY, R.W.; USRY, J.L. Plant protein ingredients with lysine supplementation reduce dietary protein level in rainbow trout (Oncorhynchus mykiss) diets, and reduce ammonia nitrogen and soluble phosphorus excretion. Aquaculture, v.218, p.553-565, 2003

FORSTER, I.P.; OGATA, H. Lysine requirement of juvenile japanese flounder Paralichthys olivaceus and juvenile red sea bream Pagrus major. Aquaculture, v.161, p.131-142, 1998.

FURUYA, W.M.; BOTARO, D.; MACEDO, R.M.G. et al. Aplicação do conceito de proteína ideal para redução dos níveis de proteína em dietas para tilápia-do-Nilo (Oreochromis niloticus). Revista Brasileira de Zootecnia, v.34, p.1433-1441, 2005.

FURUYA, W.M.; BOTARO, D.; NEVES, P.R. Exigência de lisina pela tilápia do Nilo (Oreochromis niloticus) na fase de terminação. Ciência Rural, v.34, n.6, p.1933-1937, 2004a.
FURUYA, W.M.; PEZZATO, L.E.; BARROS, M.M. et al. Use of ideal protein concept for precision formulation of amino acid levels in fish-meal-free diets for juvenile Nile tilapia (Oreochromis niloticus L.). Aquaculture Research, v.3, p.1110-1116, 2004b.

FURUYA, W.M.; PEZZATO, L.E.; MIRANDA, E.C. et al. Coeficientes de digestibilidade e valores de aminoácidos digestíveis de alguns ingredientes pela tilápia do Nilo (Oreochromis niloticus). Revista Brasileira de Zootecnia, v.30, n.4, p.1125-1131, 2001.

FURUYA, W.M.; SANTOS, V.G.; SILVA, L.C.R. et al. Exigência de lisina digestível para juvenis de tilápia-do-nilo. Revista Brasileira de Zootecnia, v.35, p.937-942, 2006.

FURUYA, W.M.; SILVA, L.C.R.; NEVES, P.R. et al. Exigência de metionina+cistina para alevinos de tilápia do Nilo, Oreochromis niloticus. Ciência Rural, v.34, n.6, p.1933-1937, 2004c.

GAYLORD, T.G.; BARROWS, F.T. Multiple amino acid supplementations to reduce dietary protein in plant-based rainbow trout, Oncorhynchus mykiss, feeds. Aquaculture, v.287, p.180-184, 2009.

GUIMARÃES, T.G.; PEZZATO, L.E.; BARROS, M.M. et al. Amino acid availability and protein digestibility of several protein sources for Nile tilapia. Aquaculture Nutrition, v.14, p.396404, 2008b.

GUIMARÃES, T.G.; PEZZATO, L.E.; BARROS, M.M. et al. Nutrient digestibility of cereal grain products and by-products in extruded diets for Nile tilapia. Journal of World Aquaculture Society, v.39, n.6, p.781-789, 2008a.

HUA, K.; BUREAU, D.P. Development of a model to estimate digestible lipid content of salmonid fish feeds. Aquaculture, v.286, p.271-276, 2009.

NATIONAL RESEARCH COUNCIL - NRC. Nutrient requirements of warmwater fishes and shellfishes. Washington, D.C.: National Academy Press, 1993. 114p.

NGAMSNAE, P.; De SILVA, S.S.; GUNASEKERA, R.M. Arginine and phenylalanine requirement of juvenile silver perch Bidyanus bidyanus and validation of the use of body amino acid composition for estimating individual amino acid requirements. Aquaculture, v.5, p.173-180, 1999.

OGATA, H.; ARAI, S.; NOSE, T. Growth response of cherry salmon Oncorhynchus masou and amago salmon O. rhodurus fry fed purified casein supplemented with amino acids. Bulletin of the Japanese Society of Scientic Fisheries, v.49, p.903908, 1983.

PEZZATO, L.E.; BARROS, M.M.; FURUYA, W.M. Valor nutritivo dos alimentos utilizados na formulação de rações para peixes tropicais. Revista Brasileira de Zootecnia, v.38, p.43-51, 2009.

PEZZATO, L.E.; MIRANDA, E.C.; BARROS, M.M. et al. Digestibilidade aparente de ingredientes pela tilápia do Nilo (Oreochromis niloticus). Revista Brasileira de Zootecnia, v.31, n.4, p.1595-1604, 2002.

QUADROS, M.; LANNA, E.A.T.; DONZELE, J.L. et al. Crude protein reduction and digestible methionine+cystine and threonine to digestible lysine ratios in diets for Nile tilapia fingerlings. Revista Brasileira de Zootecnia, v.38, n.8, p.1400-1406, 2009.

SILVA, L.C.R. L-glutamina e l-glutamato em dietas para tilápias do nilo (Oreochromis niloticus). 2008. 50f. Tese (Doutorado em Zootecnia) - Programa de Pós-Graduação em Zootecnia, Universidade Estadual de Maringá, Maringá, 2008.

SILVA, L.C.R.; FURUYA, W.M.; SANTOS, L.D. et al. Níveis de treonina em rações para tilápias do Nilo. Revista Brasileira de Zootecnia, v.35, n.4, p.1258-1264, 2006.

TAKISHITA, S.S.; LANNA, E.A.T.; DONZELE, J.L. et al. Níveis de lisina digestível em rações para alevinos de tilápia-do-nilo. Revista Brasileira de Zootecnia, v.38, n.11, p.2099-2105, 2009.

TEIXEIRA, E.A.; CREPALDI, D.V.; FARIA, P.M.C. et al. Composição corporal e exigências nutricionais de aminoácidos 
para alevinos de tilápia (Oreochromis sp.). Revista Brasileira de Saúde e Produção Animal, v.9, n.2, p.239-246, 2008.

VERTEGEN, M.W.A.; JONGBLOED, A.W. Cristalline amino acids and nitrogen emission. In: D'MELLO, J.P.F. (Ed.) Amino acids in animal nutrition. Edinburgh: CABI, 2003. p. 449-48.

VIDAL, L.V.O. Equações de predição para valores de proteína e energia digestíveis em alimentos de origem animal para tilápias. 2010. 30f. Dissertação (Mestrado em Zootecnia) - Universidade Estadual de Maringá, Maringá, 2010.

VIOLA, S.; LAHAV, E. Effects of lysine supplementation in practical carp feeds on total protein sparing and reduction of pollution. The Israeli Journal of Aquaculture, v.43, p.1112-1128, 1991.

WILSON, R.P. Amino acids and proteins. In: HALVER, J.E.; HARDY, R.W. (Eds.) Fish nutrition. New York: Academic Press, 2002. p.143-179.

WILSON, R.P.; POE, W.E. The relationship of whole body and egg essential amino acid patterns to amino acid requirement patterns in channel catfish (Ictalurus puncatus). Comparative Biochemistry and Physiology, v.80B, p.373-376, 1985.

WU, G.; MEIER, S.A.; KNABE, D.A. et al. Endogenous synthesis of arginineplays na important role in maintaining arginine homeostasis in postweaning growing pigs. Journal of Nutrition, v.127, p.2342-2349, 1997. 